During the eclipse of June 30, 1954, the Sun was unusually inactive, and it was possible to deduce the distribution of sources of ionizing radiation across it. It was found that there was an intensification near the east and west limbs, and a weakening near the poles. The results coincided closely with the distribution of decimetre radio noise radiation over the solar disk.

The $E$-layer character figure and the intensity of the 10-cm. wave-length noise radiation appear to be closely related as regards their variation from day to day, their variation with the solar cycle, and their variation over the solar disk. It cannot yet, however, be concluded that both types of radiation have a common origin. Recent estimates of how the temperature varies with height in the solar atmosphere suggest that the chromosphere and lower corona, which are responsible for most of the decimetre wave emission, would not make as important a contribution to the ionizing radiation as would the Lyman continuum from photospheric levels. A comparison of the ionospheric curves with those of solar noise emission on 3,10 and $20 \mathrm{~cm}$. wave-lengths might enable the height of emission of the ionizing radiation to be established.

\title{
OBITUARIES
}

Sir Percival Hartley, C.B.E., F.R.S.

Sir Percival Hartiey, formerly director of the Department of Biological Standards at the National Institute for Medical Research, London, died in London on February 16 at the age of seventy-five. $\mathrm{He}$ was born on May 28, 1881, at Calverly in Yorkshire and was educated at the University of Leeds, where he graduated B.Sc. in 1905 . With a Grocer's Company Research Scholarship he went to the Lister Institute of Preventive Medicine, London. In 1909 he obtained a D.Sc. in the University of London and joined the staff of the Imperial Bacteriological Laboratory at Muktesar in India. In 1913 he returned to the Lister Institute.

During the First World War he served as a captain in the R.A.M.C., and in 1917 was awarded the Military Cross. On demobilization he spent two years at the Wellcome Research Laboratories. It was during this time that he began the study of diphtheria prophylactics with which his name will always be associated.

In 1922 he joined the staff of the National Institute for Medical Research, where he became the director of the new Department of Biological Standards, an appointment he held until he retired in 1946. During this time, Percival Hartley, more than any other man, was responsible for the introduction of the International Biological Standards. $\mathrm{H}_{\Theta}$ educated world opinion as to their need. He provided not only the immunological standards but also, frequently, methods of standardization as well.

There is no doubt that the years he spent at the National Institute for Medical Research were both the happiest and most productive of his life. His work on the prevention of diphtheria is well known, but it is seldom appreciated that the regulations which he formulated to be used in Great Britain guaranteed the purity, safety and potency of immunological reagents in general and diphtheria prophylactics in particular.

It was remarkable that with all his administrative responsibilities and obligations he managed to find time for research. Among the many subjects he studied were the role of non-specific factors on antibody production, the nature of anaphylaxis, the care and maintenance of laboratory animals, the standard. ization and quality of media. Hartley's broth is world known.

During this time he received many honours. In 1927 he was awarded the William Julius Mickle Fellowship of the University of London. In 1936 he was appointed a Commander of the British Empire; in 1937 he was elected to the Fellowship of the Royal Society ; in 1944 he was knighted. When he retired in 1946 he laid down his heavy routine duties, but a new phase in his career developed. He held a series of appointments. During 1946-48 he was Wands. worth Fellow of the London School of Hygiene and Tropical Medicine. During 1948-49 he was at the Sir William Dunn School of Pathology in Oxford. During 1949-53 he returned to the Lister Institute. $\mathrm{He}_{\theta}$ was a member of the British Pharmacopoia Commission from 1933 until 1948, and he served on the Medical Research Council during 1949-53. Throughout this time he continued his research-in particular, the effect of purification of antitoxin on its ability to cross the placental barrier.

Hartley taught students and staff alike. His teaching was simple and practical. He spoke with authority, as one who had spent a life-time in the laboratory and had grown up with the great men and great events of the world of science. An enthusiast himself, by example he made his students enthusiastic.

In 1948 his old University of Leeds conferred on him the honorary degree of D.Sc. In his oration he talked of the history of diphtheria prophylactics and treatment. I remember the care with which he prepared his lecture; each lantern slide produced a flood of recollection. Much of the story was from his own experience.

This précis of the successful career of a brilliant man, of his achievements and of the honours he received, gives no indication of his courtesy, his charm, the tremendous whole-hearted warmth with which he greeted his friends; his selflessness, his modesty and his kindness to his juniors. A sensitive man, who hesitated to protest unless in defence of his scientific beliefs or high principles, he was capable of a fine flow of invective when faced with stubborn inefficiency that would not yield to gentler measures. But even then he could not maintain his anger and sought the earliest opportunity to make amends.

He married Miss Olga Parnell in 1920. Lady Hartley died in 1950. $\mathrm{H}_{\Theta}$ is survived by two daughters of the marriage. $\quad$ D. A. LoNG

\section{Mr. A. G. Davis}

Arthur Georae Davis, who died at his London home on March 1 at the age of sixty-four, had long played an invaluable and peculiar part in the progress of geology in south-east England. - He was primarily an enthusiastic and highly successful collector of fossils whose zeal did not wane with the passing years. Many a fruitful temporary section would have 
remained neglected but for his efforts, and some of the more permanent exposures yielded rich harvests as the result of his periodic visits. Among localities especially associated with his name are the Isle of Sheppey, Abbey Wood, Kent (where be collaborated with Mr. F. J. Epps), and Swanscombe, Kent.

Davis, however, did much more than collect. $\mathrm{He}$ studied and described many of the fossils, particularly the smaller ones such as Polyzoa and Foraminifera, which he obtained, and applied this work to general problems of correlation. Important among his palæontological papers are those on Lutetian Polyzoa (1934), the Foraminifera and correlation of the Bracklesham Beds (1937, in collaboration with A. Wrigley), and an Eocene Rhabdopleura of his own collecting (1949, in collaboration with H. D. Thomas).
During the last few years of his life he took up the study of Pleistocene and Holocene non-marine Mollusca. $\mathrm{He}$ also collected and had an extensive knowledge of early geological books and maps.

Davis was for many years an amateur, but in 1935 was appointed to the palæontological staff of the Anglo-Iranian Oil Co., Ltd., and on his retirement in 1954 was attached to the Foraminifera Section of the Zoology Department of the British Museum (Natural History). He worked there and then attended a meeting of the Royal Society on the day before his death. He received in 1928 the Foulerton Award of the Geologists' Association and in 1943 the Murchison Award of the Geological Society of London. He was president of the Conchological Society during 1952-54. L. R. Cox

\section{NEWS and VIEWS}

\section{Chemistry in the University of Exeter:}

Prof. H. T. S. Britton

Is September, Prof. H. T. S. Britton will retire from the chair of chemistry in the University of Exeter. He was appointed lecturer in chemistry in the University College of the South West in 1928 and became professor in 1935. For the past five years he has been director of the Washington Singer Laboratories. A lively and vigorous personality, Prof. Britton has always taken an active part in the academic affairs of the College, not infrequently finding himself in conflict with the views of his colleagues. Under his guidance many students have taken external degrees of the University of London, including a substantial number of higher degrees. Impatient of the delay in obtaining university status for the College, but working constantly towards that end, he has had the satisfaction of seeing his hopes realized during his tenure of office (see Nature, 176, 899 ; 1955). Before he retires the first Exeter degrees will have been conferred on some of his students.

Prof. Britton's research interests have been centred on the physico-chemical investigation of reactions in solution, mainly by measurements of the potentials of electrolytic cells incorporating hydrogen, glass and metal electrodes, but including also electrical conductance, diffusion and dialysis, phase rule studies, polarimetry and a number ${ }^{-o f}$ subsidiary techniques. His book, "Hydrogen Ions", now in its fourth edition, is an indispensable standby in every laboratory concerned with the physico-chemical behaviour of solutions of electrolytes. The numerous original papers which he and his research students have published have played an important part in the development of the chemistry of ionic solutions from a largely descriptive to a quantitative science.

Prof. Britton will be succeeded by Prof. H. N. Rydon, since 1952 professor of chemistry and director of the Applied Chemistry Laboratories in the Manchester College of Science and Technology (see Nature, 170, 142; 1952).

\section{Royal Geographical Society: Medals and Awards,} 1957

H.M. The QueEn has approved the award of the Royal Medals of the Royal Geographical Society as follows: Patron's Medal : Prof. Ardito Desio, director of the Geological Institute, University of Milan, leader of the suceessful Italian expedition to
$K .2(28,250 \mathrm{ft}$.$) , in 1954$, for Himalayan exploration and research; Founder's Medal: Sir George Binney, for services to Arctic exploration.

The Council of the Society has made the following awards : Victoria Medal: Prof. S. W. Wooldridge, King's College, London, for services to geographical studies, and for contributions to the geology, geomorphology, and historical geography of SouthEastern England; Murchison Grant: Dr. G. C. L. Bertram, Fellow of St. John's College, Cambridge, for services to polar research; Back Grant: Dr. R. J. Harrison Church, London School of Economics, for contributions to the economic geography of Africa; Cuthbert Peek Grant: Kenneth Blaiklock, leader of the advance party, Trans-Antarctic Expedition, 1956-57; Gill Memorial: Dr. J. C. Beaglehole, Victoria University College, Wellington, for contributions to the biography of Captain James Cook; Mrs. Patrick Ness Award: J. B. Heaney, leader of the Gough Island Scientific Survey, 1956.

\section{Overseas Co-operation by the Department of} Scientific and Industrial Research

IN reply to questions in the House of Commons regarding work carried out on a repayment basis for overseas countries by the Department of Scientific and Industrial Research, the Parliamentary Secretary to the Ministry of Works, as representing the Lord President of the Council, said that work was only undertaken for overseas territories when it was likely to be of some interest to the United Kingdom. Most of the work involved testing of materials or machines, but some long-range research for the Colonies was carried out at the Building Research Station, the Road Research Laboratory and the Pest Infestation Laboratory. There was close and constant interchange of information between the Department and research bodies in the United States and Canada, facilitated by the United Kingdom Scientific Mission in Washington, and so far there had been collaboration on the measurement of radio atmospheric noise, standardization in radiology, standardization of screw threads, and testing the fire resistance of pre. stressed concrete beams. Giving further details of the five projects on aspects of building practice in which the Department was collaborating with the Office of European Economic Co-opəration, Mr. H. Nicholls said that no definite conclusions had yet been reached but it was expected that reports would be published in due course. 